\title{
Red Wine Polyphenols Affect the Collagen Composition in the Aorta after Oxidative Damage Induced by Chronic Administration of $\mathbf{C C l}_{4}$
}

\author{
L. HLAVAČKOVÁ ${ }^{1}$, P. JANEGA ${ }^{1,2}$, A. ČERNÁ ${ }^{1}$, O. PECHÁŇOVÁ ${ }^{2}$, \\ R. ANDRIANTSITOHAINA ${ }^{3}$, P. BABÁL ${ }^{1}$
}

${ }^{1}$ Department of Pathology, Faculty of Medicine Comenius University, ${ }^{2}$ Institute of Normal and Pathological Physiology, Centre of Excellence for Cardiovascular Research, Slovak Academy of Sciences, Bratislava, Slovakia, ${ }^{3}$ Pharmacologie et Physico-Chimie des Interactions Cellulaires et Moléculaires, Université Louis Pasteur de Strasbourg, Unité Mixte de Recherche Centre National de la Recherche Scientifique 7034, Faculté de Pharmacie, Illkirch, France

Received October 23, 2007

Accepted February 20, 2008

On-line July 18, 2008

\section{Summary}

Increased amount of collagen type I and decreased amount of type III is described in various pathological processes in the vascular wall. Polyphenols were shown to have protective effect on endothelium, decrease blood pressure and prevent oxidative damage induced by various stimuli. Tetrachlormethane $\left(\mathrm{CCl}_{4}\right)$ is a toxic substance with known negative systemic effects induced by free radicals. Chronic administration of $\mathrm{CCl}_{4}$ for 12 weeks led to an increase of collagen type I and a decrease of type III in the wall of aorta. Parallel administration of red wine polyphenols significantly reduced the increase of collagen type I, at the same time the content of type III rose to the level above controls. After 4 weeks of spontaneous recovery no changes were observed. If polyphenols were administered during the recovery period, there was a decrease of type I and an increase of type III collagen content in the aorta. It can be concluded that polyphenols have a tendency to lower the amount of type I and to increase the proportion of type III collagen in the wall of the aorta. These changes are significant in prevention or in regression of changes induced by chronic oxidative stress. This effect of polyphenols is most likely the result of their influence on MMP-1 and TIMP activities through which they positively influence the collagen types I and III content ratio in the vascular wall in favor of the type III collagen.

\section{Key words}

Red wine • Polyphenols • Collagen • Aorta $\bullet \mathrm{CCl}_{4}$

\section{Corresponding author}

P. Babál, Department of Pathology, Faculty of Medicine Comenius University, Sasinkova 4, 81372 Bratislava, Slovak Republic. Email: pavel.babal@fmed.uniba.sk, Fax: +421259357592

\section{Introduction}

Polyphenolic compounds represent a wide spectrum of substances in foods including lignins (walnuts, cereals), proantocyanins (vine, pine bark), antocyanins (fruits, vegetables), isoflavons (soya beens), catechins (tea, vine), tannins (tea, nuts), quercetin (grapes, vine, onion) and naringenin (citrus fruits) (Mandelová 2005). Epidemiologic studies indicate that high intake of polyphenols in vegetables and fruits is connected with decreased cardiovascular diseases. Mechanisms that would explain the mentioned observations remain unclear. It is supposed that flavonoids improve functions of endothelial cells and inhibit platelets aggregation (Vita 2005, Číž et al. 2008). One of the important facts is the decreased oxidation of LDL in the presence of flavonoids (Miyagi et al. 1997, Hayek et al. 1997, O'Byrne et al. 2002).

Short-lasting administration of polyphenols from red wine leads to a decrease of blood pressure in normotensive rats. This hemodynamic effect is connected with the increase of endothelium-related relaxation and induction of genes expression of inducible NO-synthase

PHYSIOLOGICAL RESEARCH • ISSN 0862-8408 (print) • ISSN 1802-9973 (online)

(C) 2009 Institute of Physiology v.v.I, Academy of Sciences of the Czech Republic, Prague, Czech Republic

Fax +420 241062 164, e-mail: physres@biomed.cas.cz,www.biomed.cas.cz/physiolres 
and COX-2 in the vascular wall (Diebolt et al. 2001). Bernátová et al. (2002) reported by polyphenols evoked significant decrease of blood pressure in experimental hypertension induced by chronic inhibition of NO synthesis. They also reported decreased hypertrophy of vascular walls, improved endothelium-related relaxation responses and reduction of vasoconstrictoric reactivity. Preventive effects of red wine polyphenols on increased blood pressure, myocardial fibrosis, vascular wall remodeling and altered vascular functions were also demonstrated in this model of experimental hypertension (Pecháñová et al. 2004). The protection of functional and structural changes was ascribed to the increased NO production. However, the significance of modulation of oxidative stress by polyphenols was also pointed out.

The application of polyphenols in prevention and therapy of neoplastic processes was also investigated (Mojžíš et al. 2008). Nakazato et al. (2005) described rapid apoptosis of myeloid leukemia cells activated by catechin through modulation of reactive oxygen species production.

Collagens are a heterogeneous group of structurally related proteins of the extracellular matrix. There are roughly 27 types of collagens divided according to the structure and size of their $\alpha$ chain and tissue distribution (Boot-Handford et al. 2003). The aortic wall contains filaments of collagen, smooth muscle cells and fibers of elastin as basic structural components. It is known that the collagen fibers bear the circular tension and elastin exerts both longitudinal and transversal support. Stiffness of the vascular wall is connected with the loss of elastic tissue and the increase of collagen content (Silver et al. 2001). Main collagens present in the aortic wall are of type I and III (Satta et al. 1995).

Increased number of cells producing type I collagen has been described in every type of atherosclerotic lesions in man (Andreeva et al. 1997). It had been shown that collagen type I supports calcification of vessels in vitro (Watson et al. 1998). It also plays a role in neoangiogenesis in the plaque (Jackson and Jenkins 1991) and in organization of thrombi (Rekhter et al. 1996). Moreover, there are proofs about the relationship between collagen type I accumulation and the severity of coronary artery restenosis after angioplasty (Pickering et al. 1996). However, insufficient formation of type III collagen is linked to the occurrence of aneurysms in the abdominal aorta and cerebral arteries without (Majamaa et al. 1992, Anderson et al. 1996) or with connection to atherosclerosis (Kuga et al. 1998).

Tetrachlormethane $\left(\mathrm{CCl}_{4}\right)$ is a toxic substance from which a trichlormethyl radical is formed by P- 450 . Further process of detoxication includes trichlormethylperoxyl radical formation that produces lipoperoxidation and oxidative stress (International Programme on Chemical Safety, 1999). $\mathrm{CCl}_{4}$ is frequently used for induction of experimental liver cirrhosis (Zwart et al. 1998). Recently, it has been applied as a model of oxidative damage to vascular endothelium (Babál et al. 2006).

The aim of the present work is to evaluate how the polyphenols influence the content of collagen type I and III in the wall of aorta in experimental animals exposed to chronic oxidative stress produced by administration of $\mathrm{CCl}_{4}$.

\section{Materials and Methods}

Animals

All procedures and experimental protocols were approved by the Ethical Committee of the Institute of Normal and Pathological Physiology SAS, and conform to the European Convention on Animal Protection and Guidelines on Research Animal Use.

Male Wistar rats (3 months old) were divided into six groups ( 8 animals in each). The preventive experiment lasting for 12 weeks consisted of four groups: the control group, the group receiving $\mathrm{CCl}_{4} 0.5 \mathrm{ml} / \mathrm{kg}$ of body weight twice a week subcutaneously in a 1:1 solution with olive oil, the group receiving dried red wine extract Provinols ${ }^{\mathrm{TM}}(40 \mathrm{mg} / \mathrm{kg} /$ day $)$ in drinking water and the group receiving Provinols ${ }^{\mathrm{TM}}+\mathrm{CCl}_{4}$. In the recovery experiment, the initial 12 weeks of $\mathrm{CCl}_{4}$ treatment were followed by 4 weeks of spontaneous recovery in the first group, and recovery with Provinols ${ }^{\mathrm{TM}}$ administration in the second group of animals. To make sure that each animal received the complete dose of Provinols ${ }^{\mathrm{TM}}$, calculated amount of Provinols ${ }^{\mathrm{TM}}$ was given to each rat in the appropriate volume of water. Daily water consumption was estimated individually for every animal one week before the experiment. During the experiment, water consumption was controlled and Provinols ${ }^{\mathrm{TM}}$ concentration in the drinking fluid was adjusted, if necessary. All animals were housed at a temperature of $22-24^{\circ} \mathrm{C}$ and fed with a regular pellet diet ad libitum.

The red wine extract dry powder Provinols ${ }^{\mathrm{TM}}$ was kindly provided by Mr. D. Ageron (Société Francaise de Distillerie, Vallont Pont d'Arc, France). Polyphenols content in Provinols ${ }^{\mathrm{TM}}$ has already been reported (Diebolt et al. 2001) and it was (in $\mathrm{mg} / \mathrm{g}$ of dry powder): 

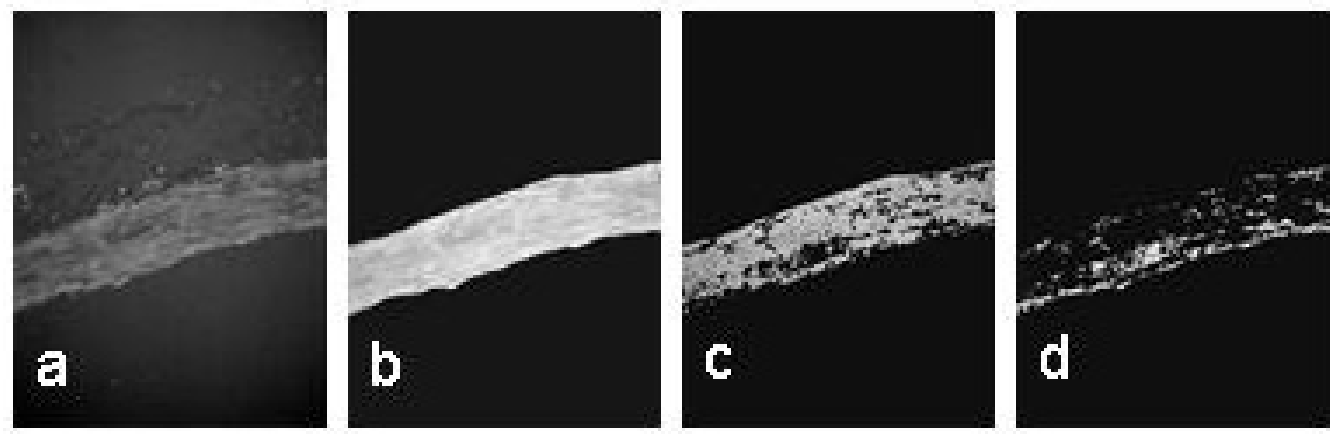

Fig. 1. Aorta stained with picrosirius red showing digitalization of the findings. (a) Aorta from $\mathrm{CCl}_{4}$-treated animal, with the perivascular fat tissue (asterix). (b) The wall of aorta deprived of perivascular fat and intima. Both types of collagen (type I is originally red and type III is green) are captured. (c) Digitally subtracted red color detecting collagen type I (d) Digitally selected green color detecting collagen type III Picrosirius red, fluorescence light, original magnification 200x.

proanthocyanidins 480, total anthocyanins 61, free anthocyanins 19 , catechin 38 , hydroxycinnamic acid 18 , flavonols 14 .

\section{Histology}

The thoracic aorta, carotid, pulmonary and renal arteries were fixed $24 \mathrm{~h}$ in $10 \%$ formalin, routinely processed in paraffin and $5 \mu \mathrm{m}$ thick slices were cut perpendicularly to the vessel axis and stained with hematoxylin and eosin. The slides were evaluated in a Leica light microscope (Leica Systeme, Wetzlar, Germany).

\section{Collagen type I and III evaluation}

Deparaffinized and rehydrated $5 \mu \mathrm{m}$ thick slices were stained with picrosirius red as follows: the slides were submerged in $0.2 \%$ phosphomolybden acid for clearing the cytoplasm, then the slides were stained with $0.1 \%$ sirius red F3BA in a saturated water solution of picric acid for $90 \mathrm{~min}$. The slides were washed $2 \mathrm{~min}$ in $0.01 \mathrm{~N} \mathrm{HCl}$, dehydrated and mounted.

The findings were documented with a digital photographic camera GC-X3E (JVC, Japan) and evaluated with ImageJ software (National Institute of Health, Bethesda, USA). Threshold values were determined for the particular colors of spectrum: from 0 to 35 for the red color corresponding to the type I collagen, from 45 to 110 for the green color corresponding to the collagen type III (Fig. 1). The numbers of pixels of each color were counted and the percentage of the whole cross-sectional area was calculated.

\section{Statistics}

The results were expressed as mean \pm S.E.M., statistically analyzed by one-way ANOVA with KeulsNeumann test.

\section{Results}

The group $\mathrm{C}$ (animals administered $\mathrm{CCl}_{4}$ ) had increased content of collagen type $\mathrm{I}$ in the wall of aorta $(56.3 \pm 2.2 \%)$. Parallel administration of $\mathrm{CCl}_{4}$ with polyphenols in the group CP lead to decreased amount of type I collagen in the aorta $(27.2 \pm 3.4 \%)$ when compared to control. The group $\mathrm{P}$ (rats administered polyphenols only) had higher amount of collagen type I $(38.3 \pm 3.8 \%)$ then CP group and lower than control group $\mathrm{K}(43.6 \pm 3.7 \%)$, but the differences were not significant (Fig. 2).

The group $\mathrm{C}$ had decreased content of collagen type III $(20.7 \pm 1.6 \%)$. Parallel administration of polyphenols with $\mathrm{CCl}_{4}$ (group $\mathrm{CP}$ ) resulted in its higher content in aortic wall $(52.7 \pm 3.9 \%)$. The group $\mathrm{P}$ contained more collagen type III $(39.4 \pm 3.9 \%)$ than control group K (29.1 $\pm 2.6 \%$ ) (Fig. 3).

After spontaneous recovery following the intoxication with $\mathrm{CCl}_{4}$, the content of collagen type I in the wall of aorta was the highest $(56.5 \pm 2.3 \%)$. If polyphenols were administered during the recovery phase, the amount of collagen type I $(8.2 \pm 1.0 \%)$ was the lowest (Fig. 4). Collagen type III content was the lowest $(18.6 \pm 1.8 \%)$ in the CR group. Conversely, administration of polyphenols during the recovery period resulted in its highest content (71.2 $\pm 3.2 \%$ ) (Fig. 5).

\section{Discussion}

Our study shows that administration of $\mathrm{CCl}_{4}$ increases the amount of collagen type $\mathrm{I}$ and, on the 


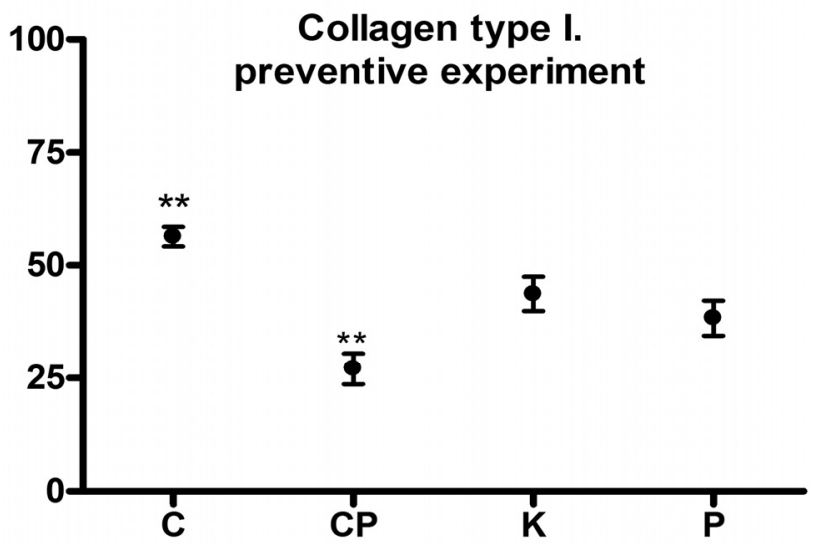

Fig. 2. Collagen type I content in the aorta after chronic intoxication with $\mathrm{CCl}_{4}(\mathrm{C})$ and the preventive effect of parallel administration of polyphenols (CP). Control group (K), polyphenols alone $(\mathrm{P})$. ${ }^{* *} \mathrm{p}<0.01$ compared to controls $\mathrm{K}$.

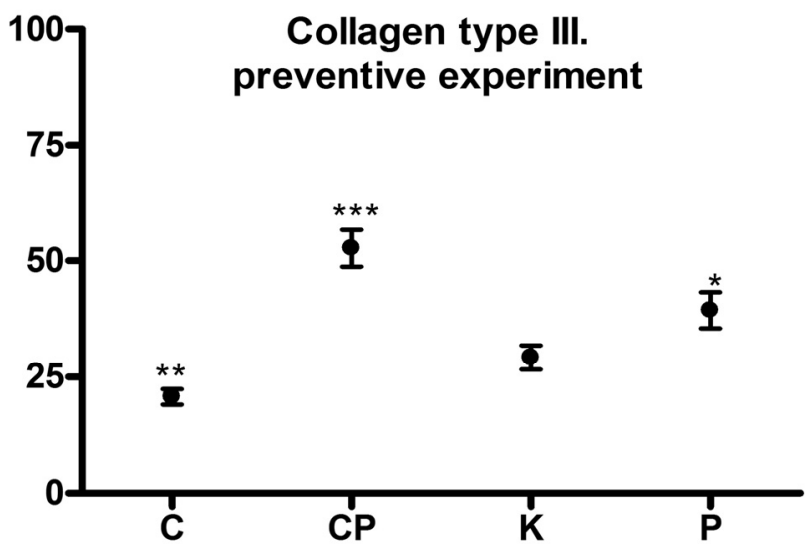

Fig. 3. Collagen type III content in the aorta after chronic intoxication with $\mathrm{CCl}_{4}(\mathrm{C})$ and the preventive effect of parallel administration of polyphenols (CP). Control group (K), polyphenols alone $(\mathrm{P}) . * \mathrm{p}<0.05, * * \mathrm{p}<0.01, * * * \mathrm{p}<0.001$ compared to controls $\mathrm{K}$.

contrary, decreases the content of collagen type III in the wall of the aorta. At present, tetrachlormethane is most frequently used for liver cirrhosis induction through the mechanism of oxidative stress (Zwart et al. 1998). It had been confirmed that chronic (10 weeks) administration of $\mathrm{CCl}_{4}$ increased the amount of collagens type I and III together with fibronectin in the liver. The oxidative damage by tetrachlormethane does not concern only the liver. Toxic damage of bone marrow and the spleen or the kidneys were also described (Singh et al. 1990). A direct relation between liver cirrhosis induced by $\mathrm{CCl}_{4}$ and vascular changes has been reported (Castro et al. 1993, Zhang et al. 1997). Recently, toxic effect of $\mathrm{CCl}_{4}$ on vascular endothelium has been published (Babál et al. 2006).

We have found that subcutaneous administration

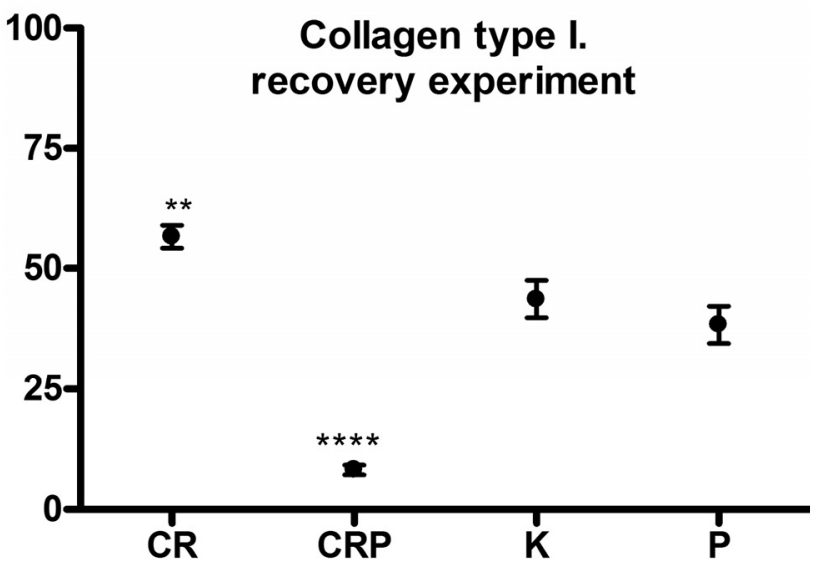

Fig. 4. Collagen type I content in the aorta after chronic intoxication with $\mathrm{CCl}_{4}$ followed by 4-week reparation phase without (CR) and with administration of polyphenols (CRP). Control group $(K)$, polyphenols administration alone $(P)$. $* * \mathrm{p}<0.01, * * * * \mathrm{p}<0.0001$ compared to controls $\mathrm{K}$.

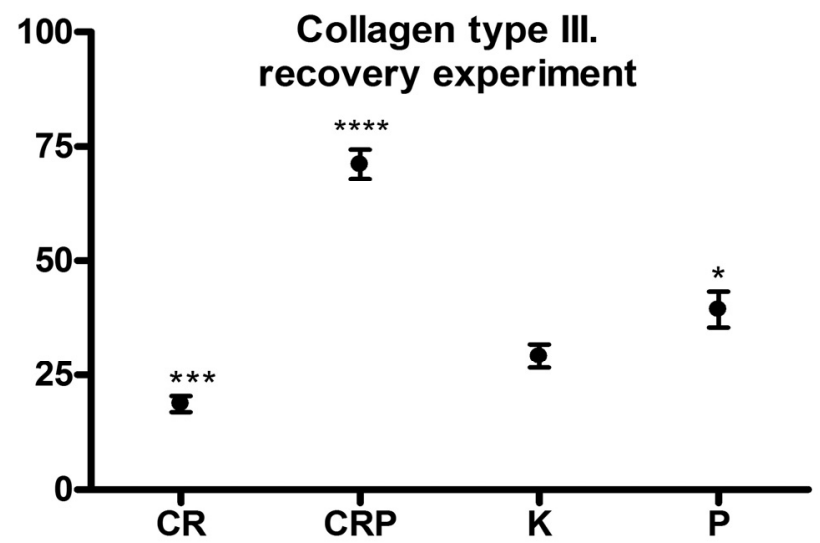

Fig. 5. Collagen type III content in the aorta after chronic intoxication with $\mathrm{CCl}_{4}$ followed by 4-week reparation period without (CR) and with polyphenols administration (CRP). Control group $(\mathrm{K})$, polyphenols administration alone $(\mathrm{P})$. * $\mathrm{p}<0.05$, $* * * \mathrm{p}<0.001, * * * * \mathrm{p}<0.0001$ compared to controls $\mathrm{K}$.

of tetrachlormethane lead to a decreased content of collagen type I and an increase of collagen type III in the of aorta. Increased amount of type I collagen in blood vessels is considered as an unfavorable factor. The increase in its production is observed in various pathological processes in blood vessels, like atherosclerosis (Andreeva et al. 1997) or coronary stenosis (Lafont et al. 1999). In contrast, the decreased amount of collagen type III was attributed to reduced elasticity of the vessels (Silver et al. 2001) and aneurysm formation (Kontusaari et al. 1990, Majamaa et al. 1992, Anderson et al. 1996).

Sirius red F3BA dissolved in the saturated picric acid solution stains collagens. Viewed under polarized or fluorescent light the color of collagen fibers depends on 
their thickness (Allon et al. 2006). Detailed study of combined usage of picrosirius red with hue analysis documented suitability of this method for evaluation of collagens (Rich and Whittaker 2005). The reliability of such analysis is supported by the results obtained by means of immunohistochemistry or expression of collagen type I and type III mRNA (Pauschinger et al. 1999).

Components of extracellular matrix are in a dynamic balance in the organism (Bissel 2001). Remodeling of the extracellular matrix includes both, the degradation and removal of its components, as well as the production and deposition of the newly synthesized components. Homeostasis of these processes influences the preservation or the changes in structure or function of the tissue (Liu and Connolly 1998). Matrix metalloproteinases (MMP) mediate the resorption of extracellular material, while the creation of extracellular matrix depends mainly on the production of collagens (Mauch 1998). Under normal physiological conditions the activity of metalloproteinases is regulated by tissue inhibitors of proteinases (Nagase and Woessner 1999). Loss of the control of MMP activity for whatever reason may result in various diseases like arthritis, atherosclerosis, aneurysm, nephritis and fibrosis (Woessner 1998).

MMP-1 is a collagenase that splits collagens type I, II and III, while type III collagen is split more effectively than the other types of collagen (Ohuchi et al. 1996). This enzyme is not produced by healthy endothelium. However, its presence is confirmed in atherosclerotic plaques (Nikkari et al. 1995) and increased amounts of MMP-1 are found in aneurysms (Lesauskaite et al. 2001). On the contrary, decreased amount of MMP-1 prevents the development of vascular lesions (Wilson et al. 2003). Tissue inhibitors of proteinases (TIMP) play an important role in maintenance of the dynamic balance of collagen matter. Their increased presence acts as a protective factor against aneurysm rupture (Allaire et al. 1998) and reduces atherosclerotic changes (Rouis et al. 1999).

Polyphenols were shown to increase TIMP expression (Lambert and Yang 2003). According to our results, the effect of polyphenols on the ratio of collagen types in the wall of the aorta is more expressed in the toxic damage induced by tetrachlormethane than in the normal control tissue. Evaluation of the control groups (with or without polyphenols) showed only a moderate shift of the ratio in favor of the type III collagen, when compared to the toxic groups. This difference might result from the damaged control mechanisms in $\mathrm{CCl}_{4}$ intoxication. Under physiological conditions, the regulatory molecules like TIMP, are able to maintain the balance between the particular units of the extracellular matrix. This could explain the less effective performance of polyphenols in the control groups. Chronic toxicity of $\mathrm{CCl}_{4}$ results in a serious systemic damage that has significant effects on the dynamic equilibrium between components of the extracellular matrix. As had been mentioned above, polyphenols inhibit the synthesis of MMP-1 (Oak et al. 2004) and increase the formation of TIMP (Lambert and Yang 2003). Through the preference of collagen type III as the substrate for MMP-1 (Ohuchi et al. 1996), the polyphenols influence the collagen types I/III ratio in favor of collagen type III. By this activity the polyphenols enhance their protective effect on blood vessels from oxidative damage caused by tetrachlormethane.

\section{Conclusions}

Subcutaneous application of $\mathrm{CCl}_{4}$ increases the amount of collagen type I and on the contrary decreases the amount of type III in the wall of the aorta. Red wine polyphenols lead to reduced content of collagen type I and increase the proportion of collagen type III in the aortic wall. This effect is enhanced after previous oxidative damage when compared with the control, and also after 4 weeks of recovery. The effect of polyphenols is most likely the result of their influence on MMP-1 and TIMP activities through which they positively influence the collagen types I and III content ratio in favor of the type III collagen.

\section{Conflict of Interest}

There is no conflict of interest.

\section{Acknowledgements}

The study was performed with partial support by APVT 20-025204, APVV-0586-06, APVV-0538-07 and VEGA $1 / 0524 / 08$. We would like to express our gratitude to Mrs. Gabika Fujeríková for technical assistance. 


\section{References}

ALLON I, VERED M, BUCHNER A, DAYAN D: Stromal differences in salivary gland tumors of a common histopathogenesis but with different biological behavior: a study with picrosirius red and polarizing microscopy. Acta Histochem 108: 259-264, 2006.

ALLAIRE E, FOROUGH R, CLOWES M, STARCHER B, CLOWES AW: Local overexpression of TIMP-1 prevents aortic aneurysm degeneration and rupture in a rat model. J Clin Invest 102: 1413-1420, 1998.

ANDERSON DW, EDWARDS TK, RICKETTS MH, KUIVANIEMI H, TROMP G, STOLLE CA, DEAK SB, BOYD $\mathrm{CD}$ : Multiple defects in type III collagen synthesis are associated with the pathogenesis of abdominal aortic aneurysms. Ann NY Acad Sci 800: 216-228, 1996.

ANDREEVA ER, PUGACH IM, OREKHOV AN: Collagen-synthesizing cells in initial and advanced atherosclerotic lesions of human aorta. Atherosclerosis 130: 133-142, 1997.

BABÁL P, KRISTOVA V, ČERNÁ A, JANEGA P, PECHÁŇOVÁ O, DANIHEL L', ANDRIANTSITOHAINA R: Red wine polyphenols prevent endothelial damage induced by $\mathrm{CCl}_{4}$ administration. Physiol Res 55: 245-251, 2006.

BERNÁTOVÁ I, PECHÁŇOVÁ I, BABÁL P, KYSELÁ S, ŠTVRTINA S, ANDRIANTSITOHAINA R: Wine polyphenols improve cardiovascular remodeling and vascular function in NO-deficient hypertension. $A m J$ Physiol 282: H942-H948, 2002.

BISSELL DM: Chronic liver injury, TGF- $\beta$, and cancer. Exp Mol Med 33: 179-190, 2001.

BOOT-HANDFORD RP, TUCKWELL DS, PLUMB DA, ROCK CF, POULSOM R: A novel and highly conserved collagen (pro(alpha)1(XXVII)) with a unique expression pattern and unusual molecular characteristics establishes a new clade within the vertebrate fibrillar collagen family. J Biol Chem 278: 31067-31077, 2003.

CASTRO A, JIMENEZ W, CLARIA J, ROS J, MARTINEZ JM, BOSCH M, ARROYO V, PIULATS J, RIVERA F, RODES J: Impaired responsiveness to angiotensin II in experimental cirrhosis: role of nitric oxide. Hepatology 18: 367-372, 1993.

ČÍŽ M, PAVELKOVÁ M, GALLOVÁ L, KRÁLOVÁ J, KUBALA L, LOJEK A: The influence of wine polyphenols on reactive oxygen and nitrogen species production by murine macrophages RAW 264.7. Physiol Res 57: 393402, 2008.

DIEBOLT M, BUCHER B, ANDRIANTSITOHAINA R: Wine polyphenols decrease blood pressure, improve NO vasodilatation and induce gene expression. Hypertension 38: 159-165, 2001.

HAYEK T, FUHRMAN B, VAYA J, ROSENBLAT M, BELINKY P, COLEMAN R, ELIS A, AVIRAM M: Reduced progression of atherosclerosis in apolipoprotein E-deficient mice following consumption of red wine, or its polyphenols quercetin or catechin, is associated with reduced susceptibility of LDL to oxidation and aggregation. Arterioscler Thromb Vasc Biol 17: 2744-2752, 1997.

International Programme on Chemical Safety, The (World Health Organization): Environmental health criteria. Geneva, http://www.inchem.org/documents/ehc/ehc/ehc208.htm\#PartNumber:6, 1999.

JACKSON CJ, JENKINS KL: Type I collagen fibrils promote rapid vascular tube formation upon contact with the apical side of cultured endothelium. Exp Cell Res 192: 319-323, 1991.

KONTUSAARI S, TROMP G, KUIVANIEMI H, ROMANIC AM, PROCKOP DJ: A mutation in the gene for type III procollagen (COL3A1) in a family with aortic aneurysms. J Clin Invest 86: 1465-1473, 1990.

KUGA T, ESATO K, ZEMPO N, FUJIOKA K, NAKAMURA K: Detection of type III collagen fragments in specimens of abdominal aortic aneurysms. Surg Today 28: 385-390, 1998.

LAFONT A, DURAND E, SAMUEL JL, BESSE B, ADDAD F, LÉVY BI, DESNOS M, GUÉROT C, BOULANGER CM: Endothelial dysfunction and collagen accumulation. Two independent factors for restenosis and constrictive remodeling after experimental angioplasty. Circulation 100: 1109-1115, 1999.

LAMBERT JD, YANG CS: Mechanisms of cancer prevention by tea constituents. J Nutr 133: 3262-3267, 2003.

LESAUSKAITE V, TANGANELLI P, SASSI C, NERI E, DICIOLLA F, IVANOVIENE L, EPISTOLATO MC, LALINGA AV, ALESSANDRINI C, SPINA D: Smooth muscle cells of the media in the dilatative pathology of ascending thoracic aorta: morphology, immunoreactivity for osteopontin, matrix metalloproteinases, and their inhibitors. Hum Pathol 32: 1003-1011, 2001. 
LIU B, CONNOLLY MK: The pathogenesis of cutaneous fibrosis. Semin Cutan Med Surg 17: 3-11, 1998.

MAJAMAA K, SAVOLAINEN ER, MYLLYLÄ VV: Synthesis of structurally unstable type III procollagen in patients with cerebral artery aneurysm. Biochim Biophys Acta 1138: 191-196, 1992.

MANDELOVÁ L: Polyphenols: Distribution and food sources. (in Czech) Výživa a potraviny 60: 11-14, 2005.

MAUCH C: Regulation of connective tissue turnover by cell-matrix interactions. Arch Dermatol Res 290: 30-36, 1998.

MIYAGI Y, MIWA K, INOUE H: Inhibition of human low-density lipoprotein oxidation by flavonoids in red wine and grape juice. Am J Cardiol 15: 1627-1631, 1997.

MOJŽÍŠ J, ŠARISSKÝ M, PILÁTOVÁ M, VOHAROVÁ V, VARINSKÁ L, MOJŽÍŠOVÁ G, OSTRO A, URDZÍK P, DANKOVČIK R, MIROSSAY L: In vitro antiproliferative and antiangiogenic effects of Flavin7. Physiol Res 57: 413-420, 2008.

NAGASE H, WOESSNER JF JR: Matrix metalloproteinases. J Biol Chem 274: 21491-21494, 1999.

NAKAZATO T, ITO K, MIYAKAWA Y, KINJO K, YAMADA T, HOZUMI N, IKEDA Y, KIZAKI M: Catechin, a green tea component, rapidly induces apoptosis of myeloid leukemic cells via modulation of reactive oxygen species production in vitro and inhibits tumor growth in vivo. Haematologica 90: 317-325, 2005.

NIKKARI ST, O'BRIEN KD, FERGUSON M, HATSUKAMI T, WELGUS HG, ALPERS CE, CLOWES AW: Interstitial collagenase (MMP-1) expression in human carotid atherosclerosis. Circulation 92: 1393-1398, 1995.

OAK MH, EL BEDOUI J, ANGLARD P, SCHINI-KERTH VB: Red wine polyphenolic compounds strongly inhibit pro-matrix metalloproteinase-2 expression and its activation in response to thrombin via direct inhibition of membrane type 1-matrix metalloproteinase in vascular smooth muscle cells. Circulation 110: 1861-1867, 2004.

O'BYRNE DJ, DEVARAJ S, GRUNDY SM, JIALAL I: Comparison of the antioxidant effects of Concord grape juice flavonoids alpha-tocopherol on markers of oxidative stress in healthy adults. Am J Clin Nutr 76: 1367-1374, 2002.

OHUCHI E, IMAI K, FUJII Y, SATO H, SEIKI M, OKADA Y: Membrane type 1 matrix metalloproteinase digests interstitial collagens and other extracellular matrix macromolecules. J Biol Chem 272: 2446-2451, 1997.

PAUSCHINGER M, KNOPF D, PETSCHAUER S, DOERNER A, POLLER W, SCHWIMMBECK PL, KÜHL U, SCHULTHEISS HP: Dilated cardiomyopathy is associated with significant changes in collagen type I/III ratio. Circulation 99: 2750-2756, 1999.

PECHÁŇOVÁ O, BERNÁTOVÁ I, BABÁL P, MARTINEZ MC, KYSELÁ S, ŠTVRTINA S, ANDRIANTSITOHAINA R: Red wine polyphenols prevent cardiovascular alterations in L-NAME-induced hypertension. J Hypertens 22: 1551-1559, 2004.

PICKERING JG, FORD CM, CHOW LH: Evidence for rapid accumulation and persistently disordered architecture of fibrillar collagen in human coronary restenosis lesions. Am J Cardiol 78: 633-637, 1996.

REKHTER MD, O'BRIEN E, SHAH N, SCHWARTZ SM, SIMPSON JB, GORDON D: The importance of thrombus organization and stellate cell phenotype in collagen I gene expression in human, coronary atherosclerotic and restenotic lesions. Cardiovasc Res 32: 496-502, 1996.

RICH L, WHITTAKER P: Collagen and picrosirius red staining: a polarized light assessment of fibrillar hue and spatial distribution. Braz J Morphol Sci 22: 97-104, 2005.

ROUIS M, ADAMY C, DUVERGER N, LESNIK P, HORELLOU P, MOREAU M, EMMANUEL F, CAILLAUD JM, LAPLAUD PM, DACHET C, CHAPMAN MJ: Adenovirus-mediated overexpression of tissue inhibitor of metalloproteinase-1 reduces atherosclerotic lesions in apolipoprotein E-deficient mice. Circulation 100: 533-540, 1999.

SATTA J, JUVONEN T, HAUKIPURO K, JUVONEN M, KAIRALUOMA MI: Increased turnover of collagen in abdominal aortic aneurysms, demonstrated by measuring the concentration of the aminoterminal propeptide of type III procollagen in peripheral and aortal blood samples. J Vasc Surg 22: 155-160, 1995.

SILVER FH, HORVATH I, FORAN DJ: Viscoelasticity of the vessel wall: the role of collagen and elastic fibers. Crit Rev Biomed Eng 29: 279-301, 2001.

SINGH KP, ZAIDI SI, RAISUDDIN, SAXENA AK, DWIVEDI PD, SETH PK, RAY PK: Protection against carbontetrachloride-induced lymphoid organotoxicity in rats by protein A. Toxicol Lett 51: 339-351, 1990. 
VITA JA: Polyphenols and cardiovascular disease: effects on endothelial and platelet function. Am J Clin Nutr 81 (Suppl): 292-297, 2005.

WATSON KE, PARHAMI F, SHIN V, DEMER LL: Fibronectin and collagen I matrices promote calcification of vascular cells in vitro, whereas collagen IV matrix is inhibitory. Arterioscler Thromb Vasc Biol 18: 1964-1971, 1998.

WILSON D, MASSAELI H, RUSSELL JC, PIERCE GN, ZAHRADKA P: Low matrix metalloproteinase levels precede vascular lesion formation in the JCR:LA-cp rat. Mol Cell Biochem 249: 151-155, 2003.

WOESSNER JF: The matrix metalloproteinase family. In: Matrix Metalloproteinases. PARKS WC, RP (eds), Academic Press, San Diego, 1998, pp 1-13.

ZHANG P, LIANG K, LIN J, WANG T, DU L: Nitric oxide synthase activity in arterial tissues of cirrhotic rats. J Tongji Med Univ 17: 25-27, 1997.

ZWART LL, HERMANNS RCA, MEERMAN JHN, COMMANDEUR JNM, SALEMINK PJM, VERMEULEN NPE: Evaluation of urinary biomarkers for radical-induced liver damage in rats treated with carbon tetrachloride. Toxicol Appl Pharmacol 148: 71-82, 1998. 